\title{
Cashless Policy and the Nigerian Economy: A Disaggregated Approach
}

\author{
Agu, Anthony Ogbonna ${ }^{1 *}$, Agu Sunday Virtus ${ }^{2}$ \\ ${ }^{I}$ Department of Economics, Chukwuemeka Odumegwu Ojukwu University, Anambra State, Nigeria. \\ ${ }^{2}$ Department of Economics, Enugu State University of Science and Technology, Enugu, Nigeria
}

*Corresponding Author: Agu, Anthony Ogbonna, Department of Economics, Chukwuemeka Odumegwu Ojukwu University, Anambra State, Nigeria.

\begin{abstract}
The Nigerian payment systems are largely cashed based. Though the country is left behind compared to other industrial countries, its use of electronic payment system is gradually gaining prominence. The emergence of cashless policy, the systems where transactions function and operate without the use of coins or banknotes, has increased the extent of economic activities in Nigeria. This study examined the impact of cashless policy on economic growth in Nigeria, over the period of Q12010 to Q42018. It employed quarterly time series data using ordinary least squares (OLS) technique. The data was sourced from World Bank Development indicator and Central Bank of Nigeria (CBN) Statistical Bulletin, Annual Report and Statement of Account for the year 2019. The researchers subjected the data to Unit Root, Cointegration and granger causality tests. Findings from the study revealed that Cashless Policy has been a veritable tool in influencing economic performance, especially as it relates to Automated Teller Machine (ATM) transactions and Point of Sale (POS) payment patterns. Based on the findings, the study recommended that banks should invest more in information communication technology (ICT) to enhance the efficiency of e-payment systems as this will enhance the revenue of banks in the long-run and improve economic growth in Nigeria. The Central Bank of Nigeria $(C B N)$ should also embark on public enlightenment to educate the populace more on the nitty-gritty of the cashless system particularly in terms of web payment and cheque transactions. This is expected to raise the level of public awareness and reduce possible resistance by the banking public so that the economy will be well positioned to reap the benefits of cashless policy.
\end{abstract}

Keywords: Economic growth, Cashless policy, Cheques, Automated Teller Machine, Web Payments, Point of Sale.

\section{INTRODUCTION}

Over the years, the Central Bank of Nigeria (CBN) has engaged in series of reforms aimed at making the Nigerian payment system formidable. These reforms were meant to enhance the overall economic performance of Nigeria so as to place it on the right path and in tune with global trends. Since Nigeria's independence in 1960, successive reforms such as the change in economic and banking policies mainly targeted at stabilizing the economy have been channeled at enhancing social welfare and achieving other economic developmental goals.

The introduction of mobile banking, electronic banking and online transactions (cashless policy) in Nigeria has paved way for a new era of development where the use and demand for physical cash is gradually declining. The increase in emerging Information Technology (IT), has made banking services become more and more automated and less paper work than in the past as averred in the Central Bank of Nigeria (CBN) reports. Banks in Nigeria have realized that they would soon go out of corporate existence unless they keep with the pace at which Information Technology (IT) has redefined the creation of value and worth for their customers (Austin, 2016). The recent evolution of information technology in the Nigerian financial institutions posses interesting questions regarding the current economic status, logistics, and availability of instruments to guarantee economic growth and stability in the era of cashless policy.

The cashless policy was aimed at curbing some of the negative consequences associated with the usage of physical cash in the economy, including high cost of cash, high risk of using cash, high subsidy, armed robbery, inefficiency as well as corruption (CBN, 2011). Some analysts (Austin, 
2016; Muhammed (2012), Klee (2004); Swartz (2016) suggested that the increased use of cashless payment system has led to the predictions of a cashless society.

However, before the inception of cashless policy reform, various payment methods have been used to purchase goods and services, starting with the trade by barter system of transaction. The trade by barter method of transaction has been the foundation for the introduction of paper money and coins to solve the problem of double coincidence of wants and the indivisibility faced by trade by barter. The use of paper money and coins were introduced to solve the various challenges associated with trade by barter.

Developed countries like US have enjoyed various advantages inherent in cashless policy which has prompted the Central Bank of Nigeria (CBN) to adopt the policy. The Nigeria's vision to be among the largest economy by 2020 has driven her to gradually move from a pure cash economy to a cashless economy. While cash and cheques are still prevalent in some parts of the world, electronic payment mechanism like mobile payments are gaining consumer acceptance in many economies due to the high penetration of mobile phone technology (Herzberg, 2003).

In view of being one of the best economies in 2020, the CBN started implementing the cashless policy in Nigeria since 2012. The Nigerian apex bank asserted reduction in crime rates, minimized risk associated with carrying huge sums of money, reduction in banking running cost, improvement in monetary policy management of inflation and the overall growth and development of the economy of Nigeria as advantages inherent in the implementation of the cashless policy.

Nevertheless, before the introduction of cashless policy by the CBN in 2012, our financial institutions have been characterized by so many hiccups ranging from poor handling of physical cash, high cost of banking operation, leakages, money laundering and other financial related offences (Ademola, 2014).

Meanwhile, the poor implementation of cashless policy across the country has over the years contributed to high cost of cash movement and cash management by banks thereby impacting negatively on banks profitability in particular and economic growth in general. Most Nigerians are still unbanked as the slow adoption of cashless policy has as well slowed down the inculcation of savings habit necessary to encourage investment and boost economic activities and development of the aggregate economy (Nonor, 2011).

The challenges of the relatively low adoption of the use of electronic payments have seriously affected the implementation of cashless policy by bank customers, the general public as well as the commercial banks and other financial intermediaries. Some recent studies in Nigeria like, Adewoye (2013), Ajayi (2014), Alagh(2014) and Ashike (2017) could not directly examine the impact of cashless policy on Nigeria's economic performance using cashless policy variables such as value of ATM transactions, value of POS transactions and value of cheque transactions. What then could be the impact of the various cashless policy channels on the economic growth of Nigeria?

\section{REVIEW OF RELATED LITERATURE}

\subsection{Conceptual Review}

The World, according to Rogers (2012), has become a global village with the arrays of developments in the information and technology super high ways.

Ademola (2014), described cashless economy as one in which transactions are done without necessarily carrying physical cash as a means of exchange or transactions but rather with the use of credit or debit cards.

\subsection{Cashless Banking Channels}

According to Woleola (2017), the most outstanding cashless banking channels world over are mobile banking, internet banking, telephone banking, electronic card, implants, Point of Sale terminals (POS) and Automated Teller Machine (ATM). According to Tan, (2002), the automated teller machine (ATM) gives customers an easy access to his cash whenever he needs it.

\subsubsection{Mobile Banking}

This involves the use of mobile phones for settlement of financial transactions. This is a fund transfer process between customers with immediate availability of funds and the beneficiary. It uses credit 
card infrastructure for movement of payment instructions as well as secure short message service (SMS) for confirmation of receipts to the beneficiary. Mobile banking is very popular and exciting to customers given the low infrastructure requirements and the rapid increase in mobile phone penetration in the country. Services covered by this product include account balance enquiry, funds transfer, recharging of phones, changing password and bill payments. Though the product is exciting, most customers are yet to fully buy into it in Nigeria. Hence, the apex bank and other financial institutions still have a lot to do in terms of increasing awareness of its product to the saving populace in the country (Woleola, 2017).

\subsubsection{Internet Banking}

This involves conducting of bank transactions on the internet using electronic tools such as computer system without visiting the banking hall. E-commerce is greatly facilitated by internet banking and is mostly used to effect payments. Internet banking like mobile banking also uses the electronic card infrastructure for executing payment instructions and final settlement for goods and services over the internet between the merchants and the customers (Woleola, 2017). Commonly used internet banking transactions in Nigeria are settlement of commercial bills and purchase of air tickets through the websites of the merchants. Basically, this device enables a customer with a personal computer and telephone to screen his account, print his own statement of account and carry out transfer activities right in the office or at home (Gandy 2017). .

\subsubsection{Telephone Banking}

Here, customer can assess their accounts using telephone lines as a link to the financial institution's database. Services rendered here include account balance transfer; change of pin etc. This product incorporate an interactivesystem of voice prompt that guides a customer through automated provision of relevant account details (Tayo 2016). According to Tan (2000), this facility provide a customer with full control of his online transaction with minimum interference from the bank.

\subsubsection{Point of Sale (Pos)/Point of Purchase (Pop) Terminals}

PoS or PoP is the location where a transaction occurs. According to Woleola, (2017) a PoS or PoP terminal is generally referred to as the hardware and software used for checking out, the equivalent of an electronic cash register. A PoS manages the selling process by a salesperson accessible interface. The system allows the creation and printing of receipts.

\subsection{Theoretical Literature Review}

\subsubsection{The Solow-Swan Growth Theory}

This theory was propounded by Solow and Swan (1956). The neo-classical stated that technology, labour and capital are the major determinants of growth in output, and they came up with a growth model, which states that technological change or scientific innovation replaces investment as the major factor thus explaining growth in the long-run. The neo-classical stated that the level of technological change is determined exogenously, i.e. it is independent of all other factors including inflation. (Gokal \& Hanif, 2004) argued that the neoclassical economic theory of growth is built on the principle of diminishing returns of labour and diminishing returns of capital separately, and constant returns to both factors jointly.

Therefore, the production function of neoclassical growth theory is used to measure the growth and equilibrium of an economy. The function is thus:

$\mathrm{Y}=\mathrm{AF}(\mathrm{K}, \mathrm{L})$.

- $\mathrm{Y}$ denotes an economy's gross domestic product (GDP)

- K represents its share of capital

- L describes the amount of unskilled labor in an economy

- A represents a determinant level of technology

However, because of the relationship between labor and technology, an economy's production function is often re-written as $\mathrm{Y}=\mathrm{F}(\mathrm{K}, \mathrm{AL})$.

The key assumption of the neoclassical growth model is that capital is subject to diminishing returns in a closed economy. The critics have faulted this theory on the basis of the assumption that there can 
be technological progress in a country practicing closed economic system citing the Chinese closed economy around 1980's where she witnessed increasing growth in technology and the economy in general (Balami, 2006). Despite the drawbacks, the endogenous growth model is still relevant to this study as it points out the importance of technology and innovations as drivers of economic growth. These technologies and innovations in an economy which serve as drivers of economic growth can be used to explain how technological innovations employed in the cashless policy initiative in the country can help the economy to grow.

\subsection{Empirical Review}

Gresvik and Owre (2012) adopted a survey research method and studied how much it costs Norwegian banks to process various payment instruments. They found that payment cards used for cash withdrawals at ATMs cost considerably more since the transactions involve cash replenishment, maintenance and security costs. In addition, the cost of using cheques for cash withdrawals was found to be three times expensive than cash withdrawals at ATMs.

Cross country studies such as Makinde et al., (2016) analyzed patterns in the use of cash and other epayment instruments in 14 developed countries, including the US. Whilst treating payment instruments as if they are traditional goods, the authors constructed measures of the cost (analogous to prices) of various payment methods in order to study whether differences in cashless instrument usage across countries can be explained by differences in the relative prices of such instruments. The result showed that such price differences failed to determine the usage of e-banking instruments. In other words, the convenience of using a particular instrument - a factor that is not measured may outweigh the price differences that users face.

Okoye and Ezejiofor (2013) examined the significant benefits and essential elements of cashless policy, and the extent at which it can enhance the growth of financial stability in the country. Descriptive research design was adopted for the study with a sample size of 68 questionnaires arrived at using the convenience sampling technique. The data collected were subjected to face validity test, and were tested with ANOVA and chi - square $\left(\mathrm{X}^{2}\right)$ technique. The results indicated that majority of Nigerians are already aware of the policy and have agreed that the policy will help the fight against corruption and money laundering as well as reduce the risk of carrying cash. However, the major problems envisaged to hamper the implementation of the policy are cyber fraud and illiteracy. Based on their findings, they recommended that government should adopt a different strategy to educate the non-literate Nigerians about the cashless economy; and a framework should be worked out to provide cyber security in Nigeria.

Muhammad (2012) in an article titled analysis of value creation of electronic banking in Nigeria examined trends of banking habit in Nigeria across banking regimes of regulation and deregulation hinged on historical perspective of banking development in Nigeria, from the period of independence to 2012.The findings suggest a static behavior across the monetary policy regimes and thus cautioned rushing the cashless policy until measures are in place to encourage and push fast the banking culture's change for the success of the cashless economy in Nigeria.

In a like manner, Nwankwo and Eze (2013) ascertained the extent to which electronic payment affects cashless economy of Nigeria using a descriptive research design. The study indicated that the electronic system of payment has a great implication on cashless economy of Nigeria, but that it will lead to significant decrease in deposit mobilization and credit extension by Nigerian deposit money banks. They concluded that cashless system of payment need to be examined and e-payment system developed, so that people will get used to it before talking of cashless economy.

Osazevbaru and Yomere (2015) explored the benefits and challenges of the cashless policy vis-à-vis the cash based policy. Specifically, the study sought whether other Point of Sales card acceptance services' stakeholders attract a significant part of banks income in cash-less economy. To address this, secondary data were collected and content analysis applied in their data analysis. After factoring in other POS stakeholders share of income, the study found that banks' income are higher in cash-less setting than in cash based arrangement. Their findings further revealed that the cash-less policy offers immense benefits to the banking sector.

The above review of the literature gives meaning to the concept of the cashless economic policy which is rooted on the Monetary Stages of Development theory as propounded by Hildebrand in 
1878. The theory of monetary stages of development explained that an economy would develop along three stages of mediums of exchange; barter, money, and credit. The Nigerian economy, having undergone the barter and money stages is now in the third and final stage of monetary development, credit. Agu and Agu (2018) opined that the government should make more conscious efforts to promote access and availability of formal credit at an attractive and fewer requirements to improve access and develop the agricultural sector in Nigeria.

\section{MeTHOdOLOGY}

\subsection{Analytical Framework}

Of all the theoretical frameworks that have attempted to capture innovations as well as technological progress, especially as it relates to cashless policy and economic growth, the Solow-Swan growth model (1956) appears to be the most leading and suitable. The model suggested that factors such as capital growth, technical progress, and investment can significantly affect economic growth. The theory argued that economic growth can best be understood from the supply side which states:

$\mathrm{Q}=\mathrm{f}\left(\mathrm{AK} \mathrm{L}^{1-\alpha}\right)-$

Where:

$\mathrm{A}=$ the determinant level of technology or knowledge (which has been identified by several studies reviewed to be a key determinant of successful implementation of cashless policy)

$\mathrm{K}=$ Total Capital Stock

$\mathrm{L}=$ Labour Productivity

This assumed that capital does not depreciate so that investment is simply the rate of increase of capital stock usually from investment in infrastructure, and that labour grows at an exogenous constant proportion. In line with the framework above, the model of our study is developed.

\subsection{Model Specification}

This model will be used to capture the effect of cashless policy on economic growth of Nigeria.

In line with the aforementioned framework, our model is explicitly specified primarily thus:

RGDP $=\mathrm{f}(\mathrm{CHE}, \mathrm{ATM}, \mathrm{POS}, \mathrm{WEB})$

Where:

RGDP= Real Gross Domestic Product (to capture economic growth);

$\mathrm{ATM}=$ Value of transactions on Automated Teller Machines across the country

WEB $=$ Value of transactions on Online web payments

POS $=$ Value of transactions on Point of sale operations in Nigeria

$\mathrm{CHE}=$ Value of transactions on cheque payments in Nigeria

The econometric form of the model is given as:

$\mathrm{RGDP}=\beta_{0}+\beta_{1} \mathrm{CHE}+\beta_{2} \mathrm{ATM}+\beta_{3} \mathrm{POS}+\beta_{4} \mathrm{WEB}+\mu_{\mathrm{t}}$

By linearizing the equation (3) and transforming into logarithm produces:

In $\mathrm{RGDP}_{\mathrm{t}}=\beta_{0}+\beta_{1} \mathrm{InCHE}_{\mathrm{t}}+\beta_{2} \ln \mathrm{ATM}_{\mathrm{t}}+\beta_{2} \operatorname{lnPOS}_{\mathrm{t}}+\beta_{4} \mathrm{InWEB}_{\mathrm{t}}+\mu$

Where $\beta_{0}$ is the intercept of the regression equation $\beta_{1}, \beta_{2}, \beta_{3}$ and $\beta_{4}$ are the coefficient of the explanatory variables which will be estimated in achieving the goal of this work.

3.2.1. A priori Specification: $\beta 1>0, \beta 2>0, \beta 3>0, \beta 4>0$,

\subsection{Data Sources}

All the data used in this study were sourced from the World Bank Development Indicators and Central bank of Nigeria statistical bulletins of different volumes.

\subsection{Estimation Procedure}

The ordinary least square (OLS) technique was employed to obtain the numerical estimates of the coefficient parameters. The choice of this technique was made under certain assumptions: OLS has 
desirable statistical properties (efficiency, consistency, and unbiasedness). In other words, OLS estimators are best linearly unbiased, hence the choice of the technique.

\section{EMPIRICAL RESUlTS AND DISCUSSION}

\subsection{Unit Root Test}

The first stage of the analysis is to test for the stationarity properties of the variables. The Augmented Dickey-Fuller (ADF) type of unit root test was used to establish stationarity of the data. The decision rule is that the ADF test statistic value must be greater than the Mackinnon critical value at $5 \%$ in absolute terms. The specification of the ADF equation assumes intercept and no trend. The null hypothesis underlying unit root test is that the variable under investigation has a unit root while the alternative proposes that it does not. The table 1.1 shows the summary of unit root test result conducted on the parameter at level.

Table1.1. Augmented Dickey-Fuller (ADF) Unit Root Test Result

\begin{tabular}{|l|l|l|l|l|}
\hline Variable & ADF Stat. & Critical Values & Order of integration & Significance \\
\hline LCHE & -4.977962 & -2.954021 & $1(1)$ & $5 \%$ \\
\hline LWEB & -4.384478 & -2.951125 & $1(1)$ & $5 \%$ \\
\hline LPOS & -5.119380 & -2.951125 & $1(1)$ & $5 \%$ \\
\hline LATM & -5.740293 & -2.951125 & $1(1)$ & $5 \%$ \\
\hline LRGDP & -5.381383 & -2.951125 & $1(1)$ & $5 \%$ \\
\hline
\end{tabular}

Source: Author's Compilation (2020) Using Data from CBN.

The table 1.1 represents the estimation results of unit root test. The results revealed that all the variables are stationary at first difference at $5 \%$ level of significance. This implies that the data are expected to be free from spurious and misleading regression estimates.

\subsection{Cointegration Test}

Co-integration analysis is carried out to determine the existence of long-run relationship that exists between the dependent variable and its regressors. To identify the long run relationship among the included variables, the Johansen (1988) multiple cointegration test was employed by using a lag length of one year suggested by Schwarz Information Criterion (SIC). These tests results are summarized below:

Table1.2. Cointegration Test Result

\begin{tabular}{|l|l|l|l|l|}
\hline Unrestricted Cointegration Rank Test (Trace) & Prob.** \\
\hline $\begin{array}{l}\text { Hypothesized } \\
\text { No. of CE(s) }\end{array}$ & Eigenvalue & $\begin{array}{l}\text { Trace } \\
\text { Statistic }\end{array}$ & $\begin{array}{l}0.05 \\
\text { Critical Value }\end{array}$ \\
\hline None & 0.533958 & 64.51409 & 69.81889 & 0.1232 \\
\hline At most 1 & 0.454622 & 38.55581 & 47.85613 & 0.2783 \\
\hline At most 2 & 0.285754 & 17.94242 & 29.79707 & 0.5703 \\
\hline At most 3 & 0.173685 & 6.500459 & 15.49471 & 0.6363 \\
\hline At most 4 & 0.000411 & 0.013978 & 3.841466 & 0.9057 \\
\hline
\end{tabular}

Source: Author's Compilation (2020) Using Data from CBN.

Table1.3. Cointegration Test

\begin{tabular}{|l|l|l|l|l|}
\hline Unrestricted Cointegration Rank Test (Maximum Eigenvalue) \\
\hline $\begin{array}{l}\text { Hypothesized } \\
\text { No. of CE(s) }\end{array}$ & Eigenvalue & $\begin{array}{l}\text { Max-Eigen } \\
\text { Statistic }\end{array}$ & $\begin{array}{l}0.05 \\
\text { Critical Value }\end{array}$ & Prob.** \\
\hline None & 0.533958 & 25.95828 & 33.87687 & 0.3233 \\
\hline At most 1 & 0.454622 & 20.61340 & 27.58434 & 0.3003 \\
\hline At most 2 & 0.285754 & 11.44196 & 21.13162 & 0.6032 \\
\hline At most 3 & 0.173685 & 6.486481 & 14.26460 & 0.5516 \\
\hline At most 4 & 0.000411 & 0.013978 & 3.841466 & 0.9057 \\
\hline $\begin{array}{l}\text { Max-eigenvalue test indicates no cointegration at the 0.05 level } \\
* \text { denotes rejection of the hypothesis at the 0.05 level } \\
* * \text { MacKinnon-Haug-Michelis (1999) p-values }\end{array}$ \\
\hline
\end{tabular}

Source: Author's Compilation (2020) Using Data from CBN. 
The result of the Johansen co-integration presented in tables 1.2 and 1.3 were carried out assuming linear deterministic trend in co-integrating equation. The trace test indicates no co-integrating equation at 5\% significance level likewise, the Max-Eigen value. This implies that long-run equilibrium relationship does not exist between the real GDP variables and value of transactions on Automated Teller Machines across the country, online web payments, Point of sale operations in Nigeria and cheque payments in Nigeria.

Table1.4. OLS Regression result

\begin{tabular}{|l|l|l|l|l|}
\hline Variable & Coefficient & Std. Error & t-Statistic & Prob. \\
\hline C & -138.4503 & 8.619596 & -16.06227 & 0.0000 \\
\hline LCHE & 0.100055 & 0.118075 & 0.847386 & 0.4033 \\
\hline LATM & -0.072022 & 0.035040 & -2.055449 & 0.0483 \\
\hline LPOS & 8.540225 & 0.507487 & 16.82845 & 0.0000 \\
\hline LWEB & -0.312621 & 0.168495 & -1.855375 & 0.0731 \\
\hline R-squared & 0.993083 & Mean dependent var & 8.155414 \\
\hline Adjusted R-squared & 0.992190 & S.D. dependent var & 2.326098 \\
\hline F-statistic & 1112.616 & Durbin-Watson stat & 1.955800 \\
\hline Prob(F-statistic) & 0.000000 & \multicolumn{2}{|l}{} \\
\hline
\end{tabular}

Source: Author's Compilation (2020) Using Data from CBN.

The signs of the coefficients of the explanatory variables, LCHE and LPOS, obtained are both positive and conform to apriori expectations. On the other hand, LWEB and LATM coefficients have negative signs and do not conform to apriori expectations. The negative signs of online web payment and Automated Teller Machine results might have been influenced by internet hitches that have frequently characterized Nigeria's cashless transactions over the years. This findings are in line with Abdul et al (2014), who posit that the success or failure of non cash payment channels depend on reliable infrastructural facilities like robust telecommunications, constant energy supplies and widespread availability of point of interaction machines. The inconsistency in most of the ATM terminals across the country increasingly cast some doubts in the minds of the majority of bank customers on the reliability or safety of these modes (Onuorah 2018).

The result also showed that the intercept is -138.4503 , which implies that the mean value of the gross domestic product would be put at -138.4503 when all the variables determining it are held constant.

The positive coefficient of (LCHE) 0.100055 for cheque means that an increase in value of cheque payments will improve economic growth by about $10 \%$. The LPOS coefficient of 8.540225 denotes that an increase in the POS services will lead to $854 \%$ economic growth. The LATM coefficient of 0.072022 implies that a unit increase in value of transactions on automated teller machines across the country will decrease economic growth by $7.2 \%$. In the same vein, a unit change in online web payments, decreases economic growth by $31 \%$ as indicated by the coefficient of -0.312621 for LWEB.

The coefficient of series: LATM $(0.0483)$ and LPOS $(0.0000)$ have their t-statistic probabilities to be less than $5 \%$. The implications are that both value of transactions on automated teller machines across the country and value of transactions on Point of sale operations in Nigeria have significant impacts on economic growth in Nigeria. This implies that the payment system plays a crucial role in the functioning of the economy. It also affects the extent of economic activity, the operations of economic agents and the effectiveness and efficiency of the economy as a whole.

On the other hand, the coefficient of cheque value, LCHE (0.4033) and online web payments LWEB (0.0731) have no significant impact on economic growth in Nigeria having their t-statistic probabilities to be greater than 5\%. This further indicates that cheque payments in Nigeria and Online web payments have not been fully embraced by bank customers in Nigeria. This runs contrary to the target of making Nigerian economy a prosperous one.

The $\mathrm{R}^{2}$ measures the overall goodness of fit of the entire regression model. From our results obtained, the value of $\mathrm{R}^{2}$ is shown to be 0.993083 . This implies that the independent variables accounts for about $99 \%$ of variations in the dependent variable (Economic growth), while the remaining $1 \%$ of the variation in economic growth are accounted for by variables outside the model which were accounted for by the error term. The implication of the findings is that cashless policy is a strong determinant of economic growth in Nigeria. It also indicates that other variables outside the model are negligible 
and considered not significant. This findings are in line with Agbola (2016), who revealed that there has been a very modest move away from cash. Payments are now being automated and absolute volumes of cash transactions have declined.

\subsection{Test of Autocorrelation}

The study undertook only the serial correlation test given that test for unit root and co-integration as stated in the previous section has been carried out in the pre-mortem analysis. To accomplish the aim of test of serial correlation, we employed the Durbin-Watson test.

Using the rule of thumb, we compared the DW statistic with an approximation of two (2) to accept or reject the hypothesis of presence or absence of serial correlation. The Durbin-Watson statistic of 1.955800 as on table 1.4 indicates evidence of no serial correlation in the data adopted for this study.

Table1.5. Granger causality test results

\begin{tabular}{|l|l|l|l|l|}
\hline Null Hypothesis: & Obs & F-Statistic & Prob. & Decision \\
\hline LCHE does not Granger Cause LRGDP & 34 & 0.00323 & 0.9968 & Accept \\
\hline LRGDP does not Granger Cause LCHE & 34 & 3.37673 & 0.0480 & Reject \\
\hline
\end{tabular}

Source: Author's Compilation 2020 Using Data from CBN.

In the Granger Causality test, we observed the direction of cause-effect relationship among variables. This provides the basis for determining which variable takes the lead for responses by other variables. The Granger causality test results were presented on the table 1.5. The results show that the null hypothesis of causality running from LCHE to LRGDP would be accepted, while the causality running from LRGDP to LCHE would be rejected. Thus, we conclude that only cashless policy granger causes economic growth in Nigeria and not otherwise.

\section{CONCLUSION AND RECOMMENDATIONS}

Empirical studies have shown that cashless policy is linked to economic growth. Following the objectives, the study estimated the real GDP as a function of Automated Teller Machines, Online web payments, Point of sale operations and Cheque payments in Nigeria. The findings of the study showed that the value of cheque payments and point of sales operations have a positive relationship with economic growth in Nigeria. On the other hand, the values of transactions on automated teller machines, and online web payments have a negative relationship with economic growth in Nigeria.

The implications of these results are that since there is negative and significant impact of ATM transactions on economic growth in Nigeria, further regulatory framework that will check electronic banking fraud should be put in place by the government to enlighten bank customers who make use of ATMs on the dangers inherent in the transactions. The commercial banks as well as the CBN should embark on public enlightenment campaign to educate the populace on the nitty-gritty of the cashless system especially as it relates to web payment and cheque transactions. This will raise the level of awareness and reduce possible resistance by the banking public so that the economy will reap the benefits of cashless policy

The cashless policy serves as a good tool in influencing economic growth especially as it relates to the value of cheque and POS payment patterns.

\section{REFERENCES}

[1] Abdul, M. Hussein, English and Adewunmi, Paul (2014).

[2] Ademola, A. S (2014). Recapitalization and banks performance: A case study of Nigerian Banks\|, African Economic and Business Review, 6(1): 27-41

[3] Agbola, A. A. (2016). Electronic payment system and tele-banking services in Nigeria, Journal of Internet Banking and Commerce, vol. 11, No. 3

[4] Agu, A. O. \& Agu, N. J. (2018). Credit access and agricultural output in Nigeria. IDOSR journal of humanities and social sciences 3(1): 51-67, ISSN:2550-7966

[5] Ajayi, M. (2014), Banking sector reforms and banking consolidation: conceptual framework\|, Bullion, 29(2): 60-74

[6] Akara, R (2016). Prospects and challenges of mobile money in Nigeria economyll, retrieved from http://www.thisdaylive.com/articles/prospects-and-challenges-of-mobile-money-onnigeriaeconomy/129273 
[7] Alagh, A. D. (2014). Nigeria's cashless economy: the Imperatives\|, International Journal of Management and Business Studies, 2(2): 31-36

[8] Ashike, H. (2017), Cashless economy can reduce risk of rarrying huge cash,[Online]Available :http://www.businessdayonline.com/.../22217

[9] Atangana, E. M., Adamou, M. S. D., \& Njie, P. K. (2016). An empirical analysis of the effects of monetary policy on economic growth in Cameroon. Merit Research Journal of Business and Management, 4(2), 009-017.

[10] Austin, A. D. (2016).The future of money; The cashless economy - Part 1\|, [Online] Available: http://www.x.com/.../future_money_cashless_economy_part_1.

[11] Balami, D. H. (2006). Macroeconomic theory and practice. Salawe prints: Maiduguri

[12] Carow, U. \& Staten, R. (2010) Benefits of cashless economy by experts\| retrieved from http://www.zumalist.com

[13] Central Bank of Nigeria, (2011). Guidelines on Point of Sales (POS) Card Acceptance Services, retrieved from www.cenbank.org

[14] Gandy, T. (2017). Banking in e-space. The banker, 145 (838), pp74-76

[15] Gokal E. K., \& Hanif B. (2004). Interest and price: foundation of a theory of monetary policy, 7. Princeton University

[16] Gresvik, N. \& Owre, O. (2012) Realizing the benefits and challenges of cashless economy in Nigeria: its perspective, International Journal of Advances in Computer Science and Technology, 1(1): 7-13

[17] Herzberg, H. (2003). The determinants of commercial bank interest margin and profitability: evidence from Tunisia. Working paper 856365. htpp://www.papers.ssrn.com/sol3/papers.cfm

[18] Humphrey, D. B. (2004), "Market failure and resource use: Economic incentives to use different payment instruments. Kluwer Academic Publisher: Boston, MA

[19] Klee, M. I. (2004). Economics of a cashless society: An analysis of costs and benefits of payment instruments, AEI-Brookings Joint Center.

[20] Makinde, R., Princewell, N. A. \& Anuforo, R., (2016). Shifting policy paradigm from cash-based to cashless economy: the Nigeria experience, retrieved from http://www.onlineresearch journals.com/aajoss/art/124.pdf

[21] Muhammed, A. (2012; Cashless policy will lower cost of accessing finance, retrieved fromhttp://www.Nigeriadevelopmentandfinanceforum.org/PolicyDialogue/Dialogue.aspx

[22] Nonor, G. (2011). The effect of bank consolidation on bank credit reduction: evidence from selected banks in Nigeria. International Journal of Business and Management Tomorrow, 2(3), 1-8

[23] Nwankwo, O. B. \& Eze, M. C (2013). Current Challenges will not stop cashless economy implementation, retrieved from http://www.archive.punchontheweb.com

[24] Nwoye, O. (2011). Cashless banking in Nigeria: challenges, benefits and policy implication, European Scientific Journal, Vol.8 (12), retrieved from eujournal.org/index.php/esj/article/view/192

[25] Okoye, C. \& Ezejiofor, A. S. (2013). Financial development and economic growth in Nigeria: A reconsideration of empirical evidence. Journal of Economics and Sustainable Development, 5(28), 199208.

[26] Osazevbaru, H. O. \& Yomere, G. O. (2015), Benefits and Challenges of Nigeria‘s Cashless Policy, Kuwait Chapter of Arabian Journal of Business and Management Review, Vol. 4, No.9; 1-8

[27] Roger in Onuorah, A.C .(2012). The International Journal of Business Management and Technology. Delta State University, Abraka.

[28] Solow, R. M. (1956). "A contribution to the theory of economic growth", Quarterly Journal of Economics, 70(1), 65-94.

[29] Swartz, R. W. (2016). Economics of a cashless society: An analysis of cost and benefits of payment instruments. International Journal of Current Research, 4(11), 362-372.

[30] Tan, M., Teo, T.S. (2002) Factors influencing the adoption of internet banking. Journal of the Association for Information System, 1 (5), pp. 1-42.

[31] Tayo, U. M. (2016). Domestic electronic payment in Nigeria: The challenges. Central Bank of Nigeria Bullion, vol. 29, no. 1

[32] Woleola, O. (2017). Nigeria in 2012: The vision of cashless economy, The Nigeria Economic Summit Group, Abuja. Retrieved from http://gadzama.com/publications/NIGERIA_2012_Vision_of_a_ Cashless_Economy.d 
[33] World Bank. (2016). Nigeria Banking Brief. World Financial Indicators 2015/16: Country Economic Briefs. Washington, DC: World Bank.

\section{AUTHORS' BIOGRAPHY}

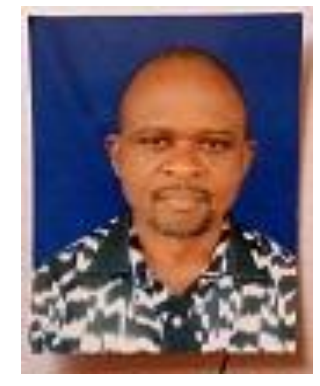

Agu Anthony Ogbonna, is a graduate of economics: B.Sc, M.Sc, and $\mathrm{PhD}$ from University of Nigeria Nsukka

Masters of Monetary economics and PhD in Public Finance and Fiscal Policy. Anthony is an Associate Professor of Economics, Chukwuemeka Odumegwu Ojukwu University, Anambra State, Nigeria.

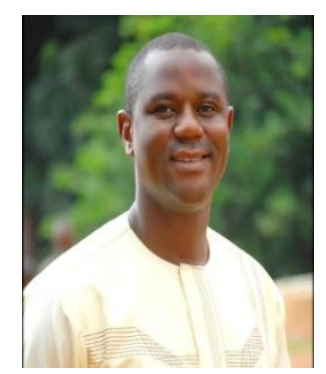

Agu Sunday Virtus, is a graduate of Economics: B.Sc University of Jos, Nigeria; M.Sc University of Nigeria Nsukka and PhD (Monetary Economics) Enugu State University of Science and Technology, Enugu, Nigeria. Sunday is a lecturer 11 at Enugu State University of Science and Technology.

Citation: Agu, Anthony Ogbonnal*, Agu Sunday Virtus. " Cashless Policy and the Nigerian Economy: A Disaggregated Approach" International Journal of Humanities Social Sciences and Education (IJHSSE), vol 7, no. 4, 2020, pp. 21-30. doi: http://dx.doi.org/10.20431/2349-0381. 0704003.

Copyright: (C) 2020 Authors. This is an open-access article distributed under the terms of the Creative Commons Attribution License, which permits unrestricted use, distribution, and reproduction in any medium, provided the original author and source are credited. 